\title{
MOÇAMBIQUE URBANA E RURAL
}

\author{
Ruy de Carvalho Monteiro ${ }^{1}$
}

Queria começar por refletir um pouquinho sobre o que é viajar. Alguém poderia dizer que viajar é encontrar-se nos outros, mas eu não creio que isso seja bem verdade, porque acho que sempre que estamos diante da alteridade somos também transformados ao invés de apenas reconhecermos nela aquilo que já estava em nós.

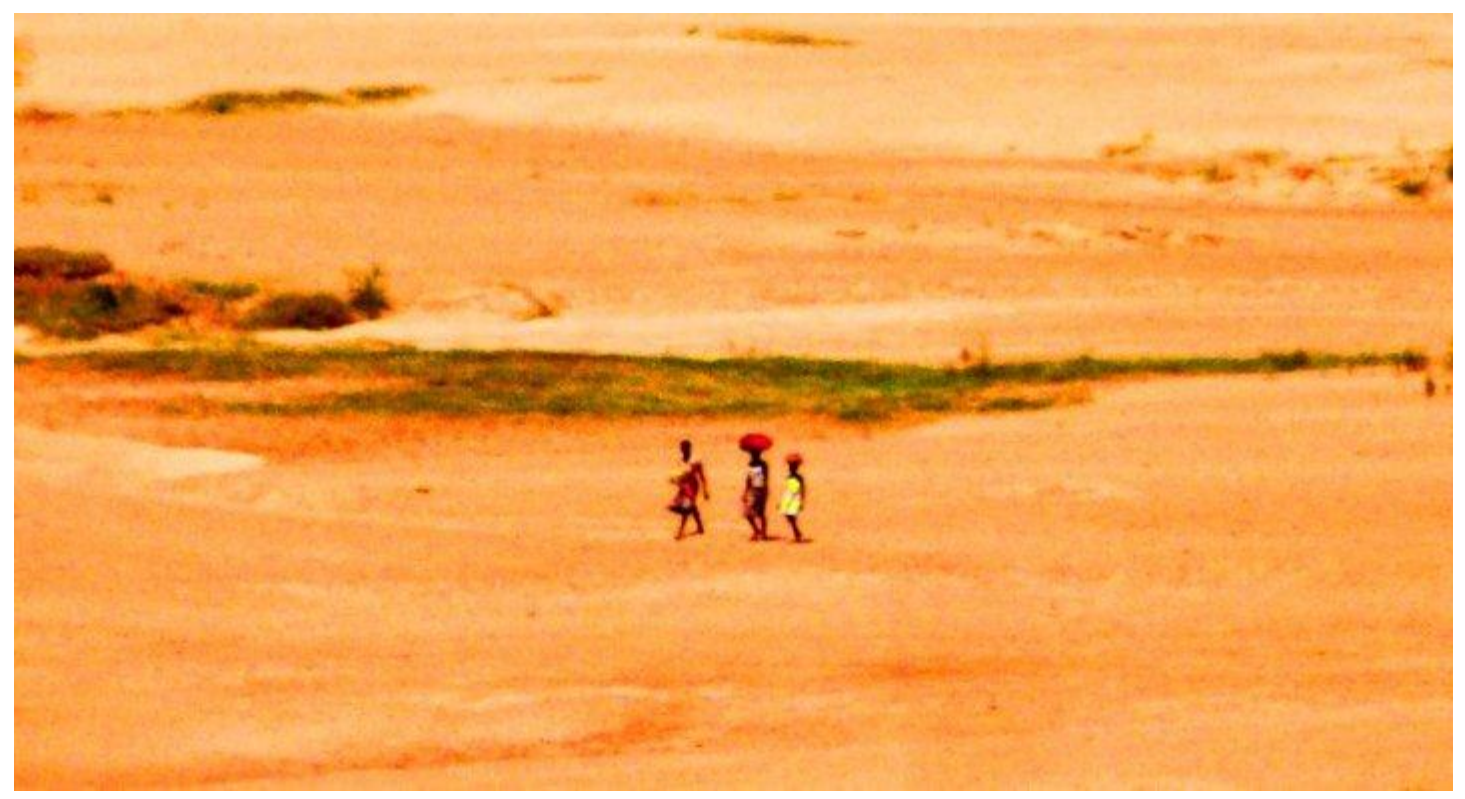

2

Assim fui por esses pensamentos e por outros tantos que me perdi enquanto viajava por Moçambique, a terra sisuda ${ }^{3}$ de Francisco

1 É graduando em Geografia pela Universidade de São Paulo. Trabalhou em Moçambique por quase dois anos entre 2008 e 2009 no Projeto de Desenvolvimento de Pequenos Produtores Orientados ao Mercado no Vale do Zambeze. Na mesma altura realizou intercâmbio acadêmico com a Universidade Eduardo Mondlane em Maputo, onde também fará seu trabalho de conclusão de curso.

2 Leito do rio Chire no inverno com mulheres indo buscar água e lavar roupa. Distrito de Mutarara.

${ }^{3}$ http:/ / www.opais.co.mz/index.php/opiniao/129-francisco-noa/13150-reinventar-a-alegria.html 
Noa, com gente muito descrente e ao mesmo tempo cheia de fé por estarem já empapuçadas com tantas falsas revoluções.

Lembro-me bem que essa foi uma das coisas, as quais eu me perguntava assim que cheguei. Porque são assim, tão descrentes e com tanta fé? Essa dúvida foi um começo. Não foi fácil respondê-la, mas acho que hoje tenho alguma idéia do motivo. Isso se a pergunta for verdadeira.

De qualquer maneira esse foi o primeiro fiozinho que puxei quando comecei a conhecer Moçambique, porque acho que conhecer é assim mesmo, a gente pega um novelo com um fiozinho meio fora do lugar que funciona como uma dúvida na nossa cabeça. Daí começa olhar pra ele e vai descobrindo o resto do fio, pra um lado e pro outro da onde vem vindo e enquanto vai seguindo vai também descobrindo todo o resto. Cada novo elemento, cada livro que lemos, cada palestra que ouvimos é mais um fiozinho que puxamos.

Pode acontecer também de o puxarmos na direção contrária e acabarmos por complicar mais o novelo, o que seria comparável a ter uma informação errada ou uma falsa impressão, mas de qualquer maneira quanto mais informações conseguimos, melhor, mesmo que seja para depois mudarmos de idéia.

Todas as dúvidas só aumentaram quando a viajem começou. Parti do aeroporto de Guarulhos, dali fui para Johannesburg, onde troquei de vôo depois de mais ou menos 1 hora de espera, para então chegar ao destino final, Maputo. Eu fiz todo o trajeto de avião, mas também é possível continuar de ônibus a partir de Johannesburg. Enfim, boa parte dessa excitação toda, devo confessar, deveu-se a um fato que pode levantar opiniões contraditórias.

A questão é que fui pra lá conhecendo pouco sobre o país, na verdade hoje vejo que conhecia quase nada, apesar de ter colegas da Geografia que já lá estavam e o trabalho com o qual já havia me envolvido me tinha obrigado a estudar um pouco as características física da região do Vale do Zambeze, pois tinha ouvido falar muito sobre as suas cheias cíclicas e a catástrofe que provocavam sistematicamente. 
Outro tanto aprendi quando escrevia o projeto para a formalização do intercâmbio. Mesmo assim era muito pouco aquilo que eu sabia sobre o pensamento, os costumes, a história, identidade e, se puder usar essa palavra sem muito rigor, a "essência" daqueles lugares e pessoas.

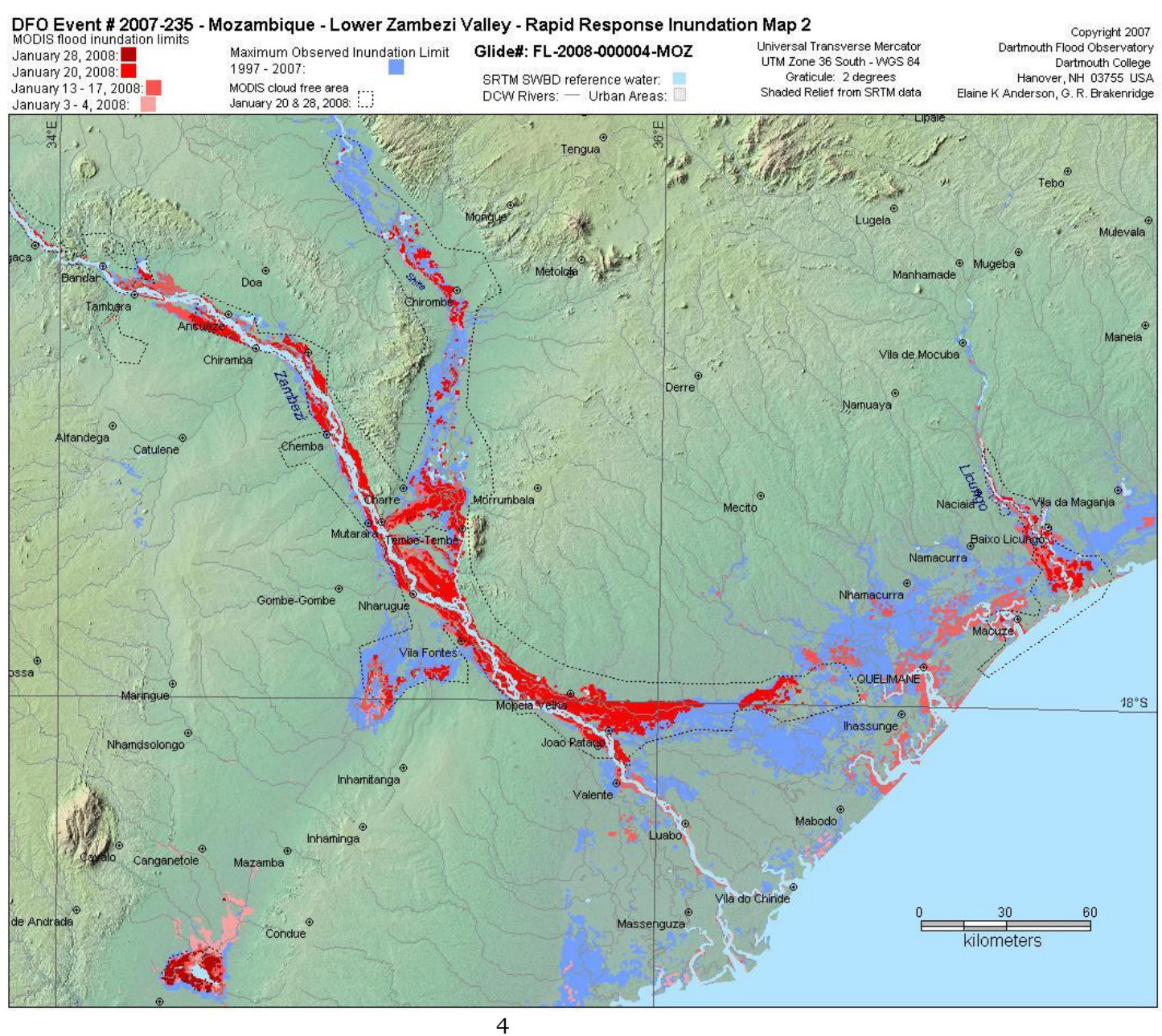

Por um lado, foi bom, porque em alguns momentos certa ingenuidade pode ser boa no sentido de não hierarquizar demais a percepção. Construir um discurso prévio pode ser um grande inibidor de experiências. Por outro, foram muitas as oportunidades que, após adentrar um pouco no contexto, sei que perdi simplesmente por desconhecer. Felizmente, para isso sempre existiu o retorno.

$\mathrm{E}$ de repente me vejo saindo do aeroporto num dia muito claro e azul de inverno, 8 de agosto. Só tinha em mãos as malas e um

\footnotetext{
${ }^{4}$ Mapa das cheias do delta do Rio Zambeze e Rio Chire em 2008. Imagem gerada por Cenacarta e retirada de:

http://www.googlecom.br/imgres?imgurl=http://www.cenacarta.com/images/cheias/2007235Zambezi.jpg \&imgrefurl=http:/www.cenacarta.com/cheias2008a.htm\&usg=
} 
papelzinho (que depois descobri ser um "papelito") com o endereço que o taxista deveria me levar.

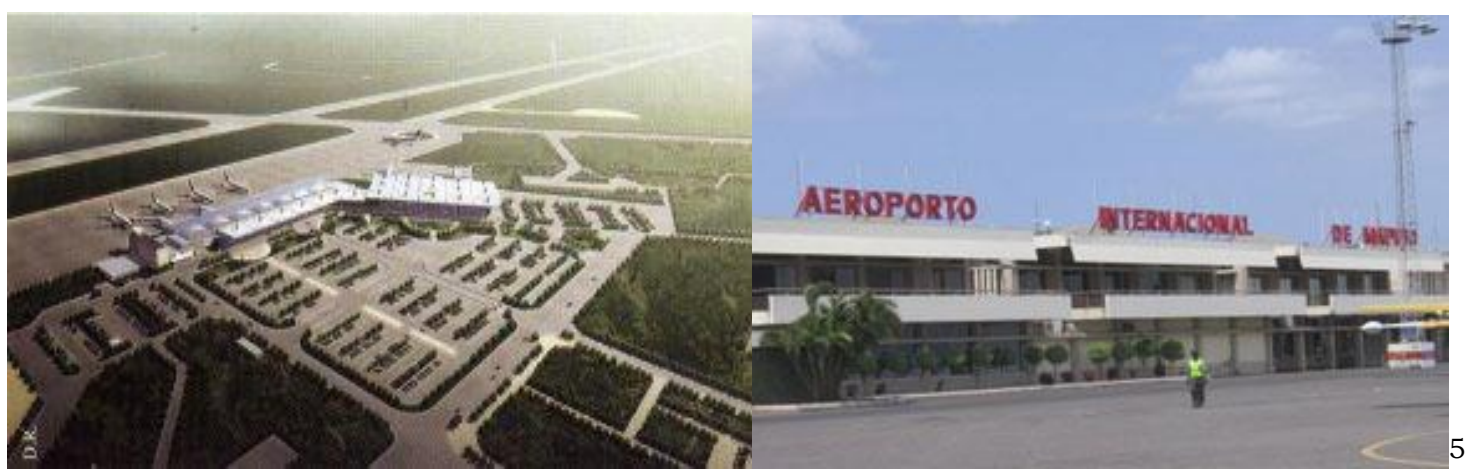

Vale dizer que hoje o aeroporto já foi totalmente reabilitado por um novo e mais moderno. Como indicador isso é importante, pois, vim saber não muito mais tarde, faz parte de um conjunto vasto de ações empenhadas em refazer ou melhorar muitas infraestruturas no bojo do processo de reconstrução pelo qual vem passando o país desde que se tornou independente de Portugal em 1975 e alcançou a paz após a guerra civil em 1992.

Assim que fizemos a volta nos estacionamentos para a saída, voltou-me à cabeça a questão da fé e da descrença, enquanto íamos passando por uma infinidade de igrejas, mesquitas entre outros tipos de templos religiosos que todo momento sucediam pela paisagem bem urbana que cruzei até o tal destino, uma "Praceta" (parecido com a nossa vila). Era casa de alguns amigos de família. Lá vivi por cerca de dois meses enquanto frequentava a faculdade nesse início.

5 Aeroporto de Maputo antigo à esquerda e aeroporto de Maputo novo à direita. Fotos tiradas de http://www.google.com.br/imgres?imgurl=http:/ 


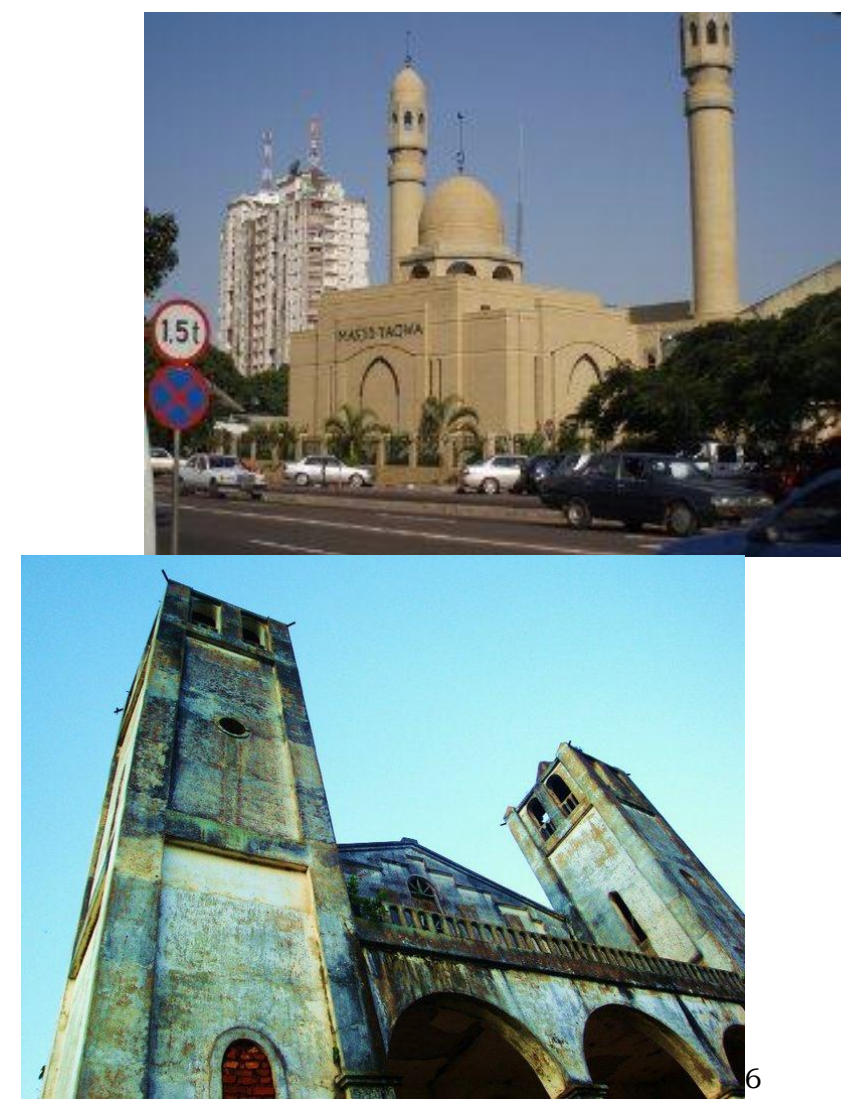

Era bem próximo à costa leste da cidade que faz fronteira com o oceano Índico no bairro da Ponta Vermelha, um lugar muito privilegiado, próximo a casa do atual presidente Armando Emilio Guebuza e dos seus pavões de estimação que sempre gostam de passear soltos pelas ruas do bairro.

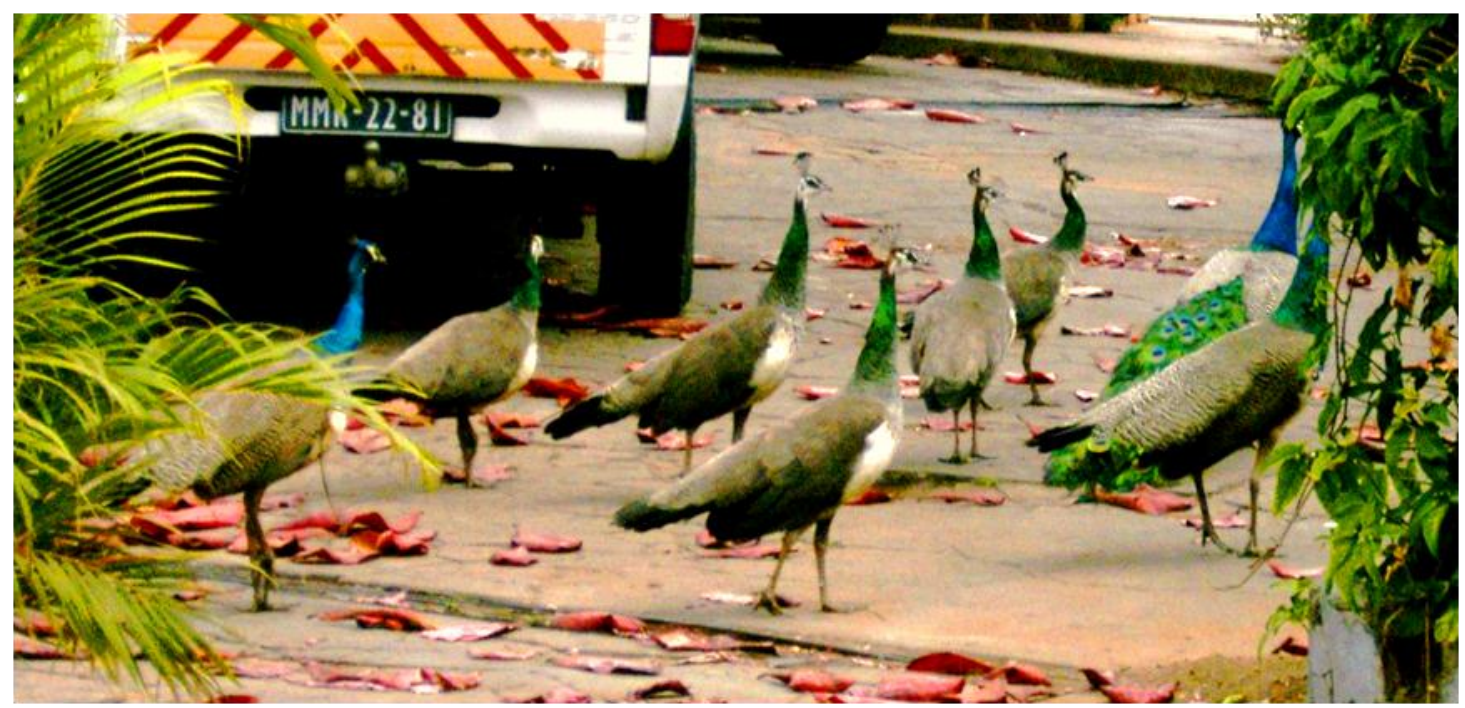

6 Fotos: da esquerda para a direita: 1 - Fachada da Igreja de Cumbapo. Distrito de Morrumbala. Província da Zambézia. 2009. Antigo colégio religioso, agora ativa como igreja evangélica. 2 - Mesquita central de Maputo vista a partir da rua. 2008. Autor: Ruy Monteiro. 
Ali vivi uma experiência muito interessante a partir da primeira amizade que fiz com o garoto que vivia em minha casa como empregado. Em muito se pareceu com a experiência retratada pelo professor José Luis Cabaço $^{8}$, quando conta que em sua infância conhecera também um garoto que vivia como criado em sua casa pelo qual criou grande afeição e amizade. Semelhante ao relato do professor, meu amigo Carlton tinha uma família que vivia no setor periurbano ou de caniço, a qual ele só podia ver aos fins de semana. Isso demonstrou uma manutenção de certas condições sociais, de trabalho e mobilidade na cidade com mais de 30 anos entre um episódio e outro.

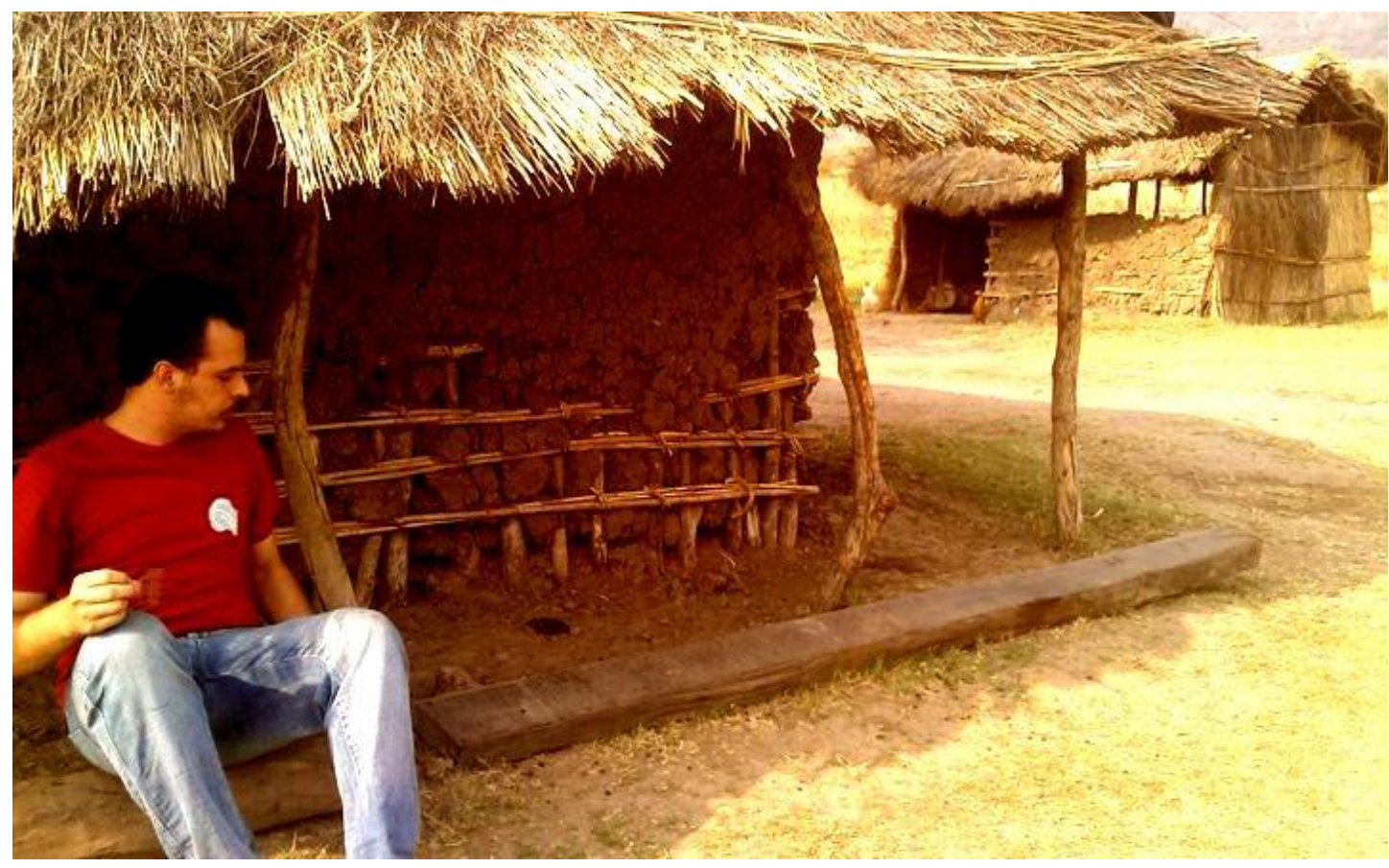

A denominação de "caniço" vem do fato de que as construções como casas, celeiros, etc. na periferia das cidades são em grande parte feitas com caniço, barro, madeira e palha, constituindo um espaço muito insalubre, pois não têm acesso ao saneamento público e muitos não chegam a ter acesso a eletricidade também. Para contornar essa situação, utilizam-se de lenha para aquecer o interior das "palhotas", como são chamadas as casas. Também a usam para cozinhar. A água é

\footnotetext{
7 http://mosanblog.wordpress.com

8 O professor fez o relato em seu livro "Moçambique. Identidade Colonialismo e Libertação"

9 Eu sentado junto a uma "palhota" feita de barro, madeira e caniço. Foto tirada por: Rosa Béltran.
} 
conseguida através de "bidões" e tem que ser buscada a grandes distâncias em rios, fontanárias, etc., sendo esse um trabalho quase sempre feminino.

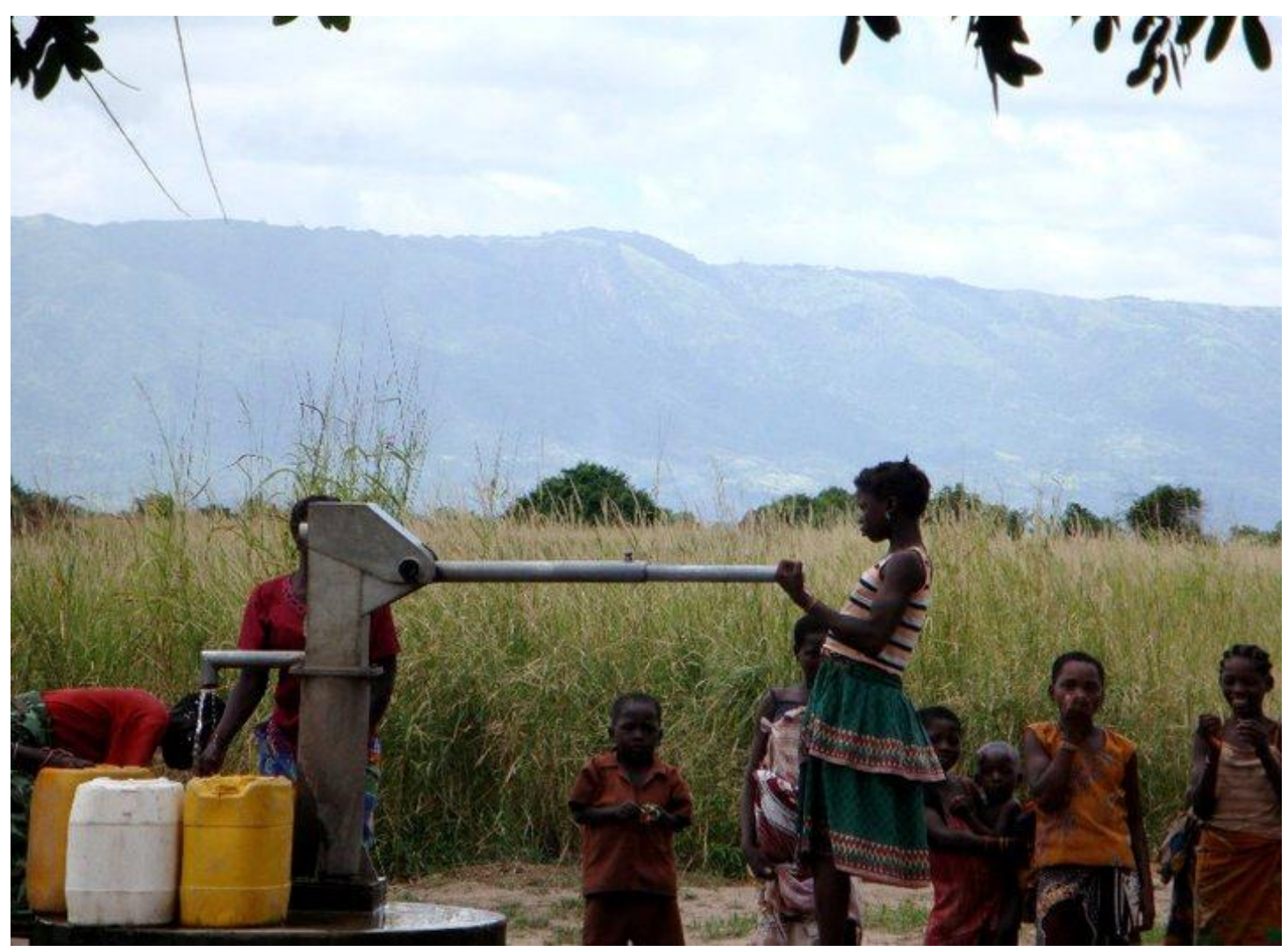

10

Naquele dia, cruzara lugares que aos poucos se tornariam muito familiares pelo cotidiano do trabalho e da faculdade. Essas, inclusive, foram ótimas maneiras perceber um pouco mais a fundo os lugares e detalhes da cultura. O trânsito estava muito calmo e espaçoso, o que me fez reparar na amplidão das avenidas larguíssimas e com canteiros centrais cheios de acácias e palmeiras plantadas por todos os lados. Mais para frente dificilmente encontraria o trânsito assim novamente. A zona de cimento sofre de um problema seríssimo de excesso de automóveis, que provocam engarrafamentos enormes nos horários de pico e falta de estacionamento na maioria das avenidas mais movimentadas. Além de falta de manutenção das vias e da poluição gerada que resulta da falta de fiscalização dos veículos que circulam, incluindo a facilidade em se trazer veículos usados com documentos

10 Meninas extraindo água de fontanária de água. Distrito de Mutarara, Província de Tete. Foto tirada por: Ruy Monteiro. 
alterados da África do Sul, que esta a curtíssimos 80 kilômetros de distância.

Dessa forma são trazidos muitos "Chapas", transportes coletivos semelhante às "Lotações" e "Micro-ônibus" do Brasil, que em muitos casos trafegam em condições de aperto muitíssimo exageradas, bem como em condições técnicas precárias. Infelizmente, é um pouco comum acontecerem acidentes envolvendo estes "Chapas", em que muitos passageiros perdem a vida, devido à falta dessas condições mínimas de segurança. Mas apesar disso, todos os dias em que estive em Maputo andei nesses transportes e no fim, com muito aperto e algum medo sai ileso.

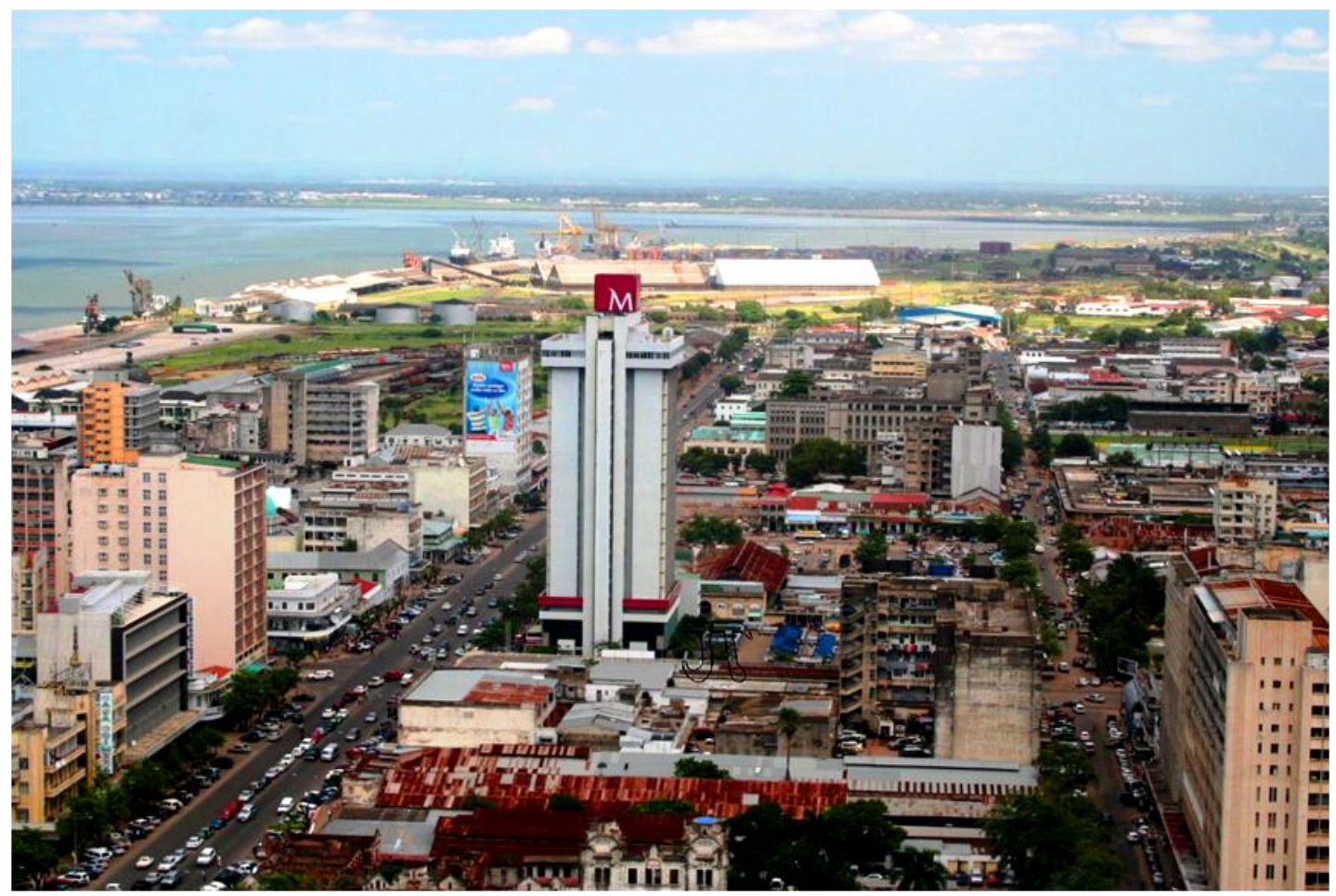

11

Durante esses trajetos sempre cruzava a magnífica cidade baixa, onde fica boa parte do comércio, sedes de bancos, quase todos os ministérios e outras repartições públicas; muitas lojas, tanto pequenas como grandes; prédios altos, como o chamado "trinta e três", que é o prédio mais alto do país com trinta e três andares, como o nome já diz; também o maior e mais novo entre os dois shoppings que existem na

${ }^{11}$ Cidade baixa de Maputo em primeiro plano, Matola ao fundo e o Rio Maputo à esquerda. Imagem retirada de: http://sulafrica.blogspot.com 
cidade, o Shopping Maputo; todo tipo de serviços dispostos em galerias, praças, lanchonetes com internet; o antigo jardim botânico, que até a altura estava bastante decadente; a sede dos Caminhos de Ferro, que é a empresa estatal responsável pelas linhas de trem; a sede da televisão estatal, TVM e a sede da Universidade Eduardo Mondlane, dentre outras tantas.

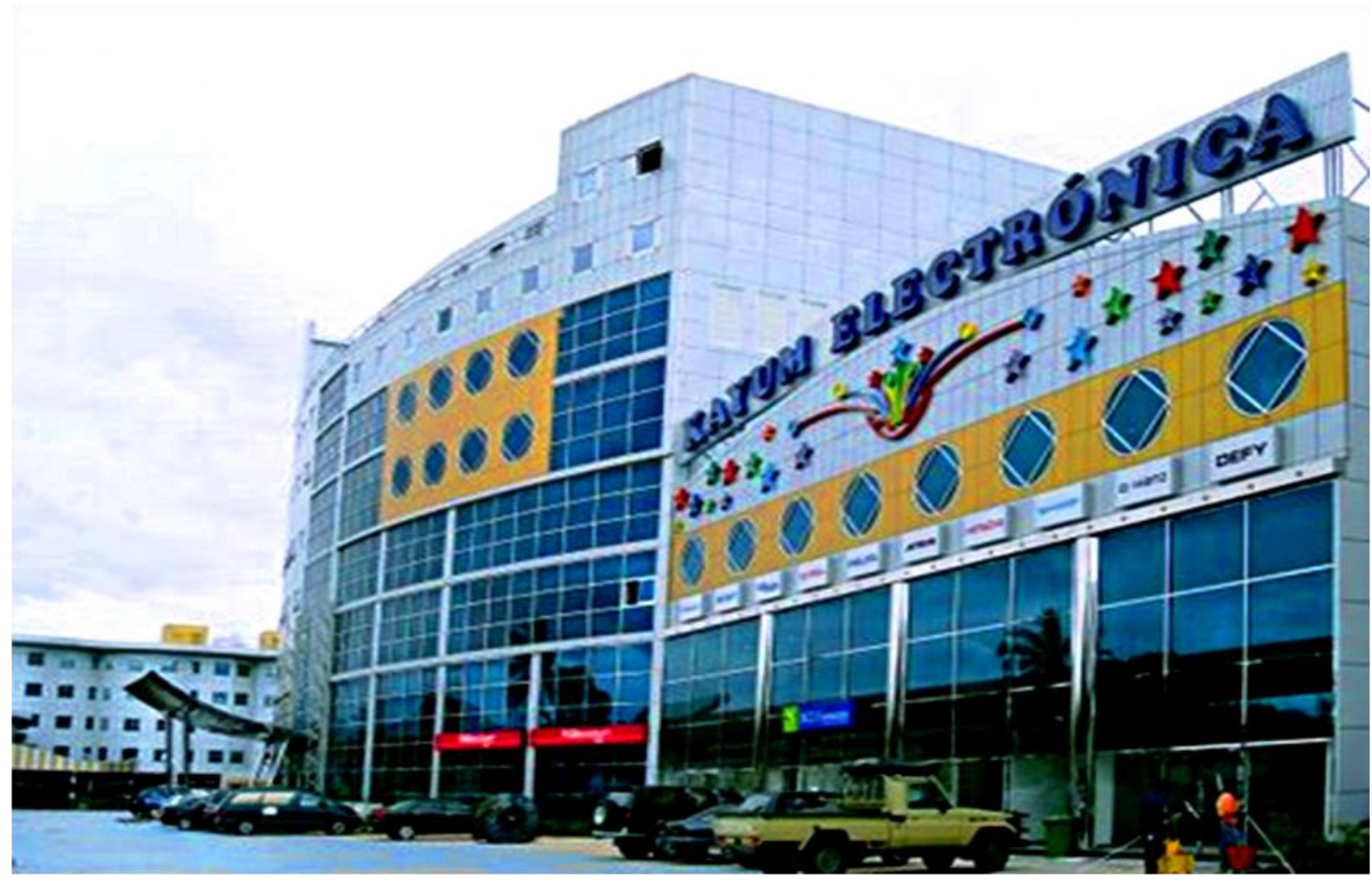

12

Um dia passei passando bem rente ao local onde foi fundada a cidade, um Forte antigo transformado em museu. A fundação da cidade esta ligada ao porto, daí se concentrarem naquele espaço grande parte do casario antigo em estilo português com prédios bastante impressionantes do ponto de vista arquitetônico.

O Mercadão de Maputo fica ali próximo e reúne a produção agrícola do entorno da cidade, além de muitos tipos de produtos industrializados que chegam por vias terrestres ou trazidos pelo porto.

Ainda não há um parque industrial muito desenvolvido nem tão diversificado dentro do território, então muitos produtos industrializados básicos são trazidos de países vizinhos, como África do

12 Maputo Shopping. Foto retirada de:


Sul. Apesar disso, houve um aumento e diversificação desse setor, principalmente na região da Matola, que é uma cidade conurbada com Maputo, onde se situam $46 \%$ de todos os postos de trabalho por causa das indústrias, que representam 30\% de todas que existem no país.

Os produtos alimentícios também sofrem com a concorrência da produção externa. Sobre isso, basta dizer que o frango de origem brasileira foi alvo de muitas críticas através da imprensa escrita, e até mesmo por propagandas massivas veiculadas na televisão em âmbito nacional, produzidas pela própria Associação Moçambicana de Avicultores, pois chega aos mercados e lojas moçambicanos mais barato e maior do que os produzidos nacionalmente. ${ }^{13}$

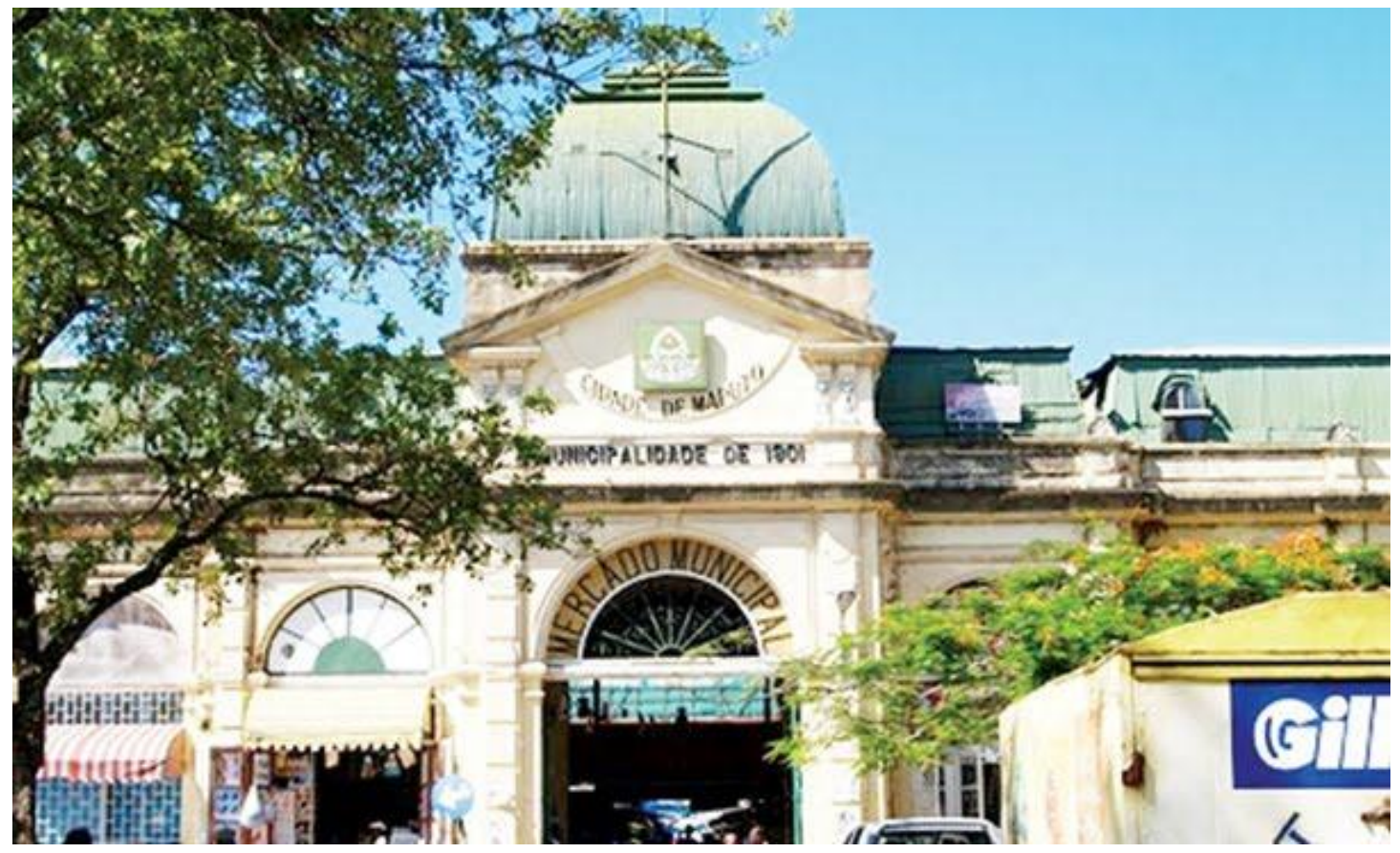

14

A todo momento eu alimentava essas perguntas, que hoje percebo, serviram para reavivar um certo olhar estrangeiro sobre as coisas, do tipo que a tudo quer se aproximar, que a tudo quer fazer perguntas. Aquele olhar dos dez primeiros dias. Queria fazê-lo durar tanto, queria mantê-lo quando já estivesse de volta ao Brasil, e se

${ }^{13}$ Vários vídeos podem ser vistos através do site do Youtube: http://www.youtube.com/watch?v=_0Pus0vr87U http://www.youtube.com/watch?v=4rpV3NfBvWI \&NR=1

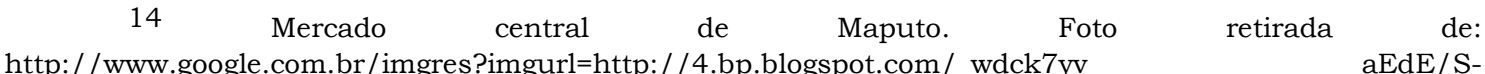
hQONshKlI/AAAAAAAABoE/Nilu51PrS90/s1600/Mercado-Central-de-Maputo.jpg\&imgrefurl=http:/ 
pudesse, pra sempre. Seria bom se nunca entrássemos pelas mesmas vias do cotidiano do pensamento.

Acho que a excitação da mudança reside aí mesmo, Moçambique foi para mim a primeira vez. Emoção desmedida, ansiedade que eu desconhecia e um desconhecimento ainda maior que não cabia. Nunca antes saíra do Brasil, portanto e de fato minha primeira vez. Fui de qualquer maneira. E não sabia nunca o que ia encontrar ali mais pra frente. Sempre essa sensação. De alguma forma pensamos que ali naquele momento e naquele lugar sempre existe a possibilidade de que seja diferente. E foi assim até o fim do primeiro ano em que lá estive. Depois disso, nos seis meses finais que se seguiram, totalizando um ano e meio de viagem, comecei a pensar que voltaria para o Brasil, só aí então é que tive de volta alguma certeza quanto aquilo que viria a encontrar.

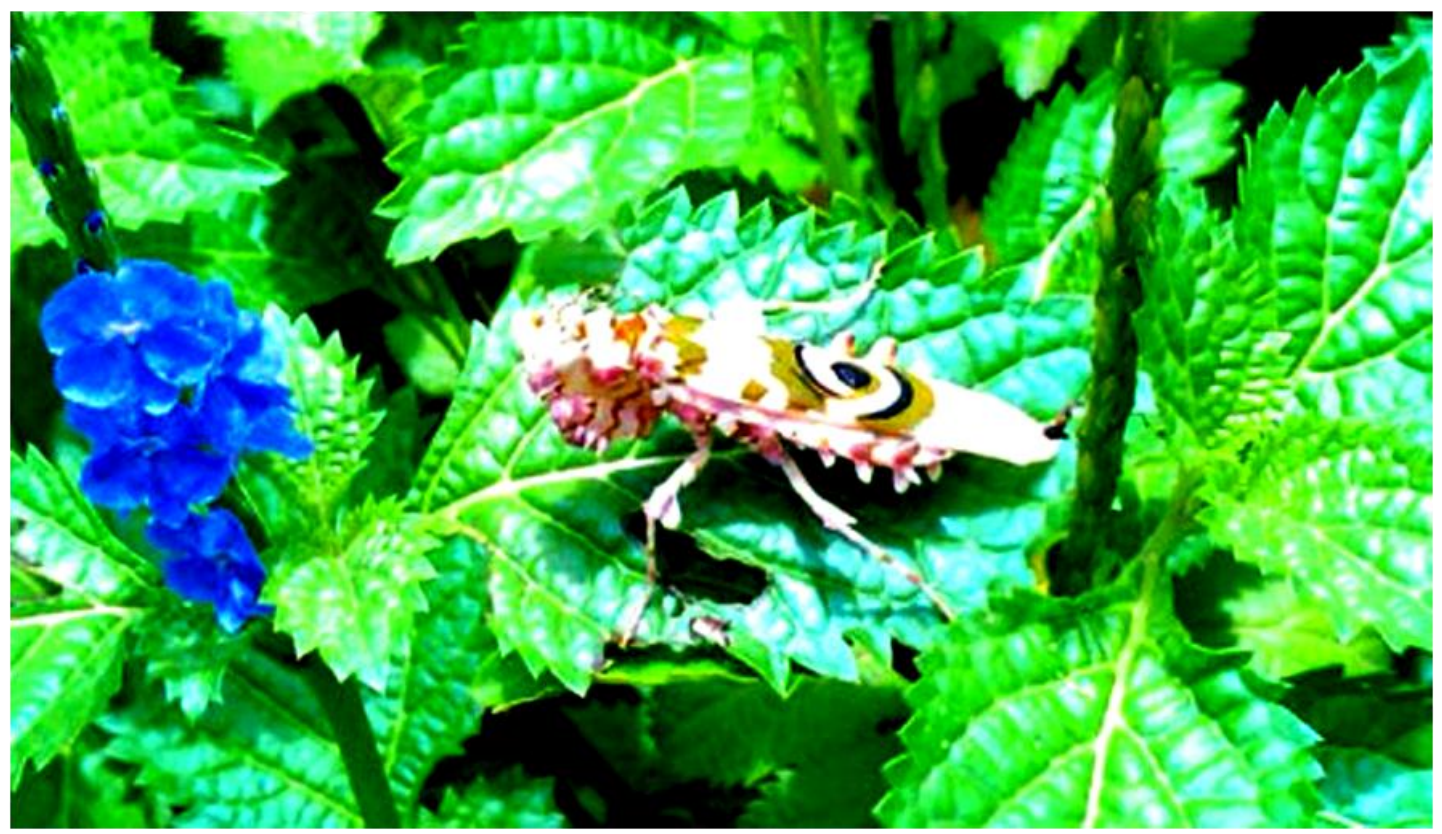

Em termos acadêmicos, todo esse aprendizado seria facilmente resumido como o resultado da socialização do indivíduo em contextos que ampliam seu leque de experiências como elemento ativo e passivo num processo de reconstrução sistemática ${ }^{16}$, mas por acreditar que “...

\footnotetext{
15 Gafanhoto peculiar. Foto: Ruy Monteiro.

${ }^{16}$ Ver Setton, Maria da Graca Jacintho. A socialização como fato social total: notas introdutórias sobre a teoria do habitus. Rio de Janeiro, RJ, 2009. p. 296-307. Revista Brasileira de Educação, Rio de janeiro, RJ, v. 14, n. 41, maio/ago. 2009. 400 p. (1413-2478).
} 
o nome estraga as coisas..."17, vamos prosseguir com o discurso em tom pouco acadêmico como forma de ir aos detalhes de um processo particular de ressocialização, o meu.

Nunca deixei de me surpreender com aquilo novo que conhecia, com aquilo velho que estava em mim e que aos pouquinhos iria, se dissiparia. Com certeza me acostumei um pouco com alguns lugares, pessoas, coisas e jeitos, e até mesmo peguei alguns para serem meus. $\mathrm{O}$ distrito de Morrumbala, na provincia da Zambézia às margens do rio Chire e do Zambeze foi um desses.

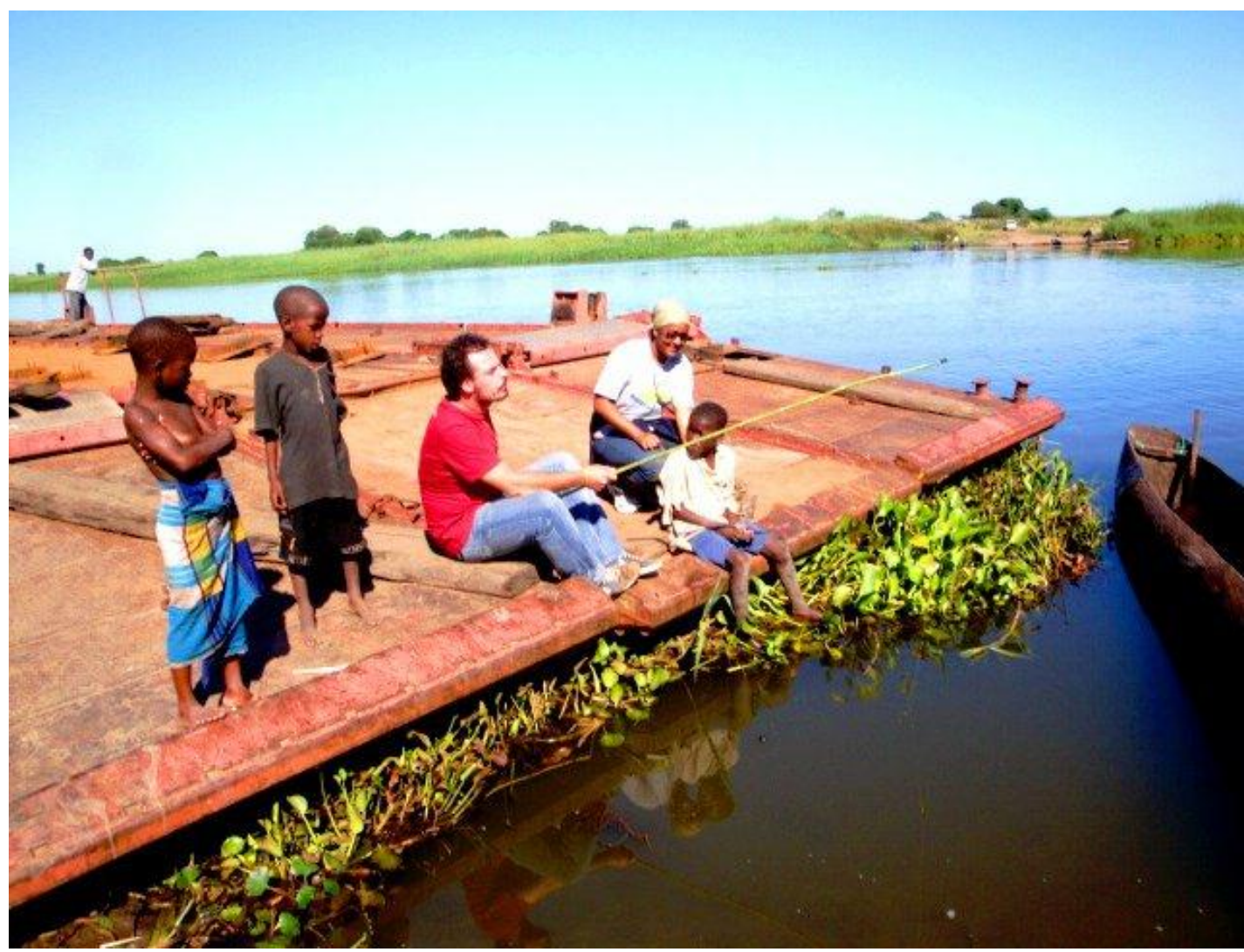

Desde uma rua que passa a ser sua conhecida, pela qual você passa e dá "bom dia" ao indiano da padaria, até jeitos de falar as mesmas coisas, por exemplo, o "maningue", que quer dizer "muito" ou o "ya", que quer dizer "sim".

O "ya" é a primeira coisa que você percebe que já esta falando e a última que você deixa de falar (e em alguns casos não deixa). O "ya"

\footnotetext{
${ }^{17}$ In. Rosa, João Guimarães. Sagarana. Rio de Janeiro, Nova Fronteira, 2006. 415 p. Edição comemorativa 60 anos (1946-2006) 18 Eu pescando no batelão avariado que fazia o cruzamento do rio Chire para o transporte de pessoas e veículos, mas, sobretudo para o algodão. Foto por: Simão Guezane.
} 
pode ser dito de muitas maneiras e pra cada uma há um significado atrelado: um "ya" simples é "sim" e pronto. Um "ya!" duro, marcado, pode querer dizer "sim, é óbvio" ou "sim, rápido", mas tem um mais interessante. Ele é dito de forma bem estendida, com um tom meio variado, meio tremido, meio assoprado, e traz a impressão de que por traz de si há todo um aprendizado de vida que por ele, no entanto, é facilmente resumido: "ya.....".

Depois dos seis meses muito proveitosos em que estudei na Universidade Eduardo Mondlane assistindo a quatro disciplinas ("cadeiras" como eles dizem), três no departamento de Geografia e uma no departamento de História, comecei a incorporar muito desses detalhes da comunicação do dia-a-dia. Para quem fará esse intercâmbio, seria interessante dizer que se faça tudo com muita antecedência e resguardo, pois os processos institucionais podem demorar muito para decorrer já que o uso de computadores não é generalizado nos departamentos públicos e universidades de lá.

Em 2008/2009, foi inaugurada a nova biblioteca da universidade, que levou o nome de um grande intelectual moçambicano, Brazão Mazula. Nela está organizado um belo acervo bibliográfico e cartográfico para ser consultado, que vem somar ao acervo já existente da biblioteca do CAP e do CEA. 


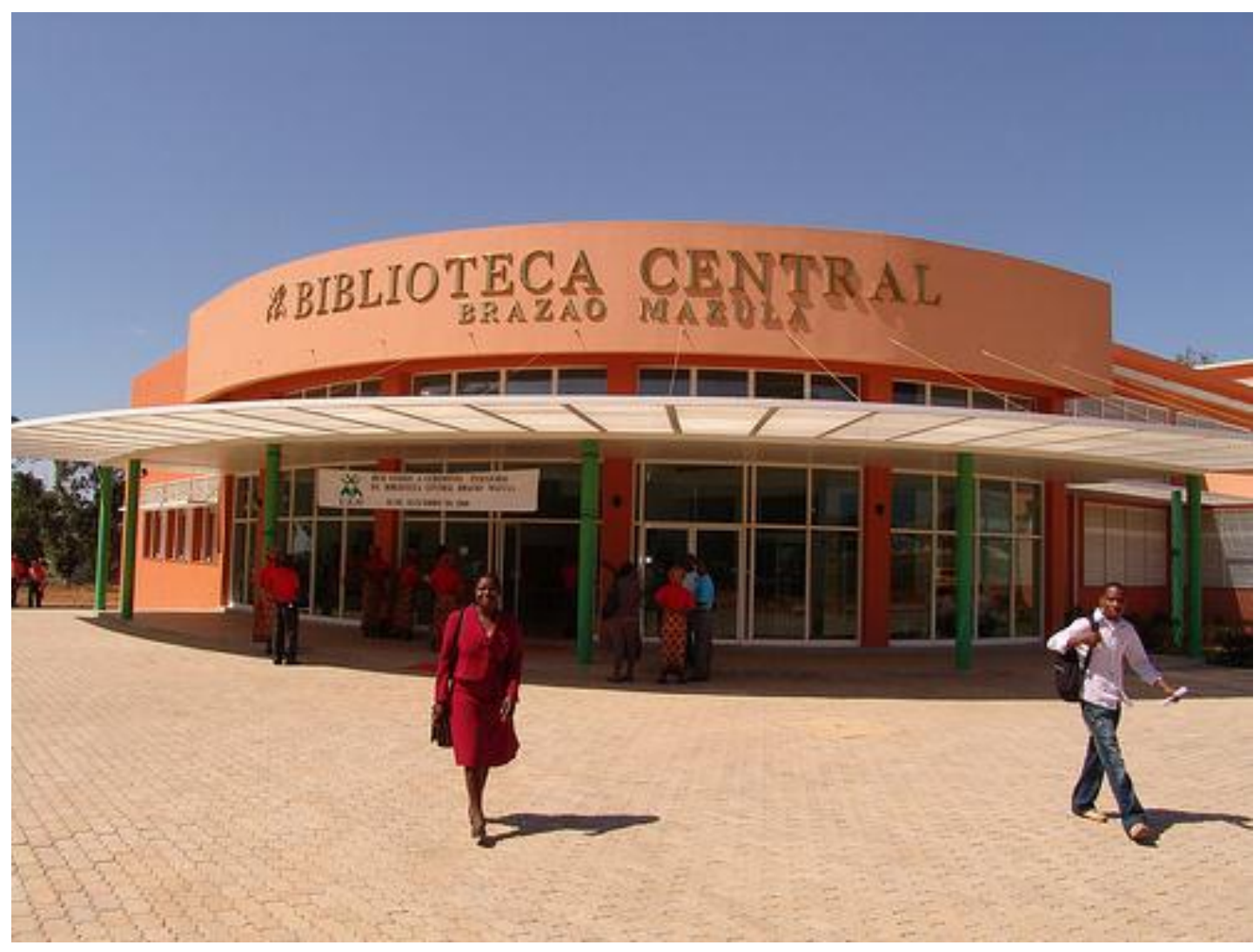

Uma grande referência que tive foi o prof. dr. Manuel Araújo20, que não esta mais no cargo que ocupava como catedrático do curso de geografia. Foi ele quem primeiro me apresentou muitas questões que hoje tenho tentado desenvolver, seja durante as aulas, seja durante almoços e cafés em que pudemos compartilhar um pouco da convivência um do outro. Seus mais importantes livros, leituras indispensáveis a quem queira compreender a formação do território, tratam justamente da questão do povoamento em suas mais diferentes formas e períodos, seja no ambiente rural e urbano, seja das estratégias do Estado ou do povoamento espontâneo, chegando a formular um

19 Nova biblioteca Brazão Mazula da Universidade Eduardo Mondlane - UEM. 2008. Foto tirada por: Ruy Monteiro.

20 Eis alguns de seus mais importantes livros:

Araújo, M. G. M., "Os espaços urbanos em Moçambique" In: GEOUSP, Espaço e Tempo, São Paulo, n ${ }^{\circ} 14$, p. 165-182, 2003.

Araújo, M. G. M., Geografia dos Povoamentos: Assentamentos humanos rurais e urbanos, Maputo: Livraria Universitária , 1997.

Araújo, M. G. M., O sistema das aldeias comunais em Moçambique; transformações na organização do espaço residencial e produtivo, Tese Ph.D., Universidade de Lisboa, 1988. 
modelo de ocupação médio para a região inclusive. Quem ocupa o cargo como catedrático substituindo-o é o prof. dr. Aniceto dos Muchangos. ${ }^{21}$

A essa altura havia conhecido muitas das teorias acerca dualidade entre colonos e nativos, cidade e campo. Até já tinha me aventurado um pouco pelos distritos adjacentes no intuito de perceber melhor essas características, mas foi só quando no primeiro semestre do ano de 2009 me mudei para a província da Zambézia, primeiramente para Quelimane e logo após para Morrumbala, onde me integrei de fato às atividades de campo do Projeto de Desenvolvimento de Pequenos Produtores Orientados ao Mercado no Vale do Zambeze, que tive então contato mais intenso com comunidades mais isoladas e pauperizadas.

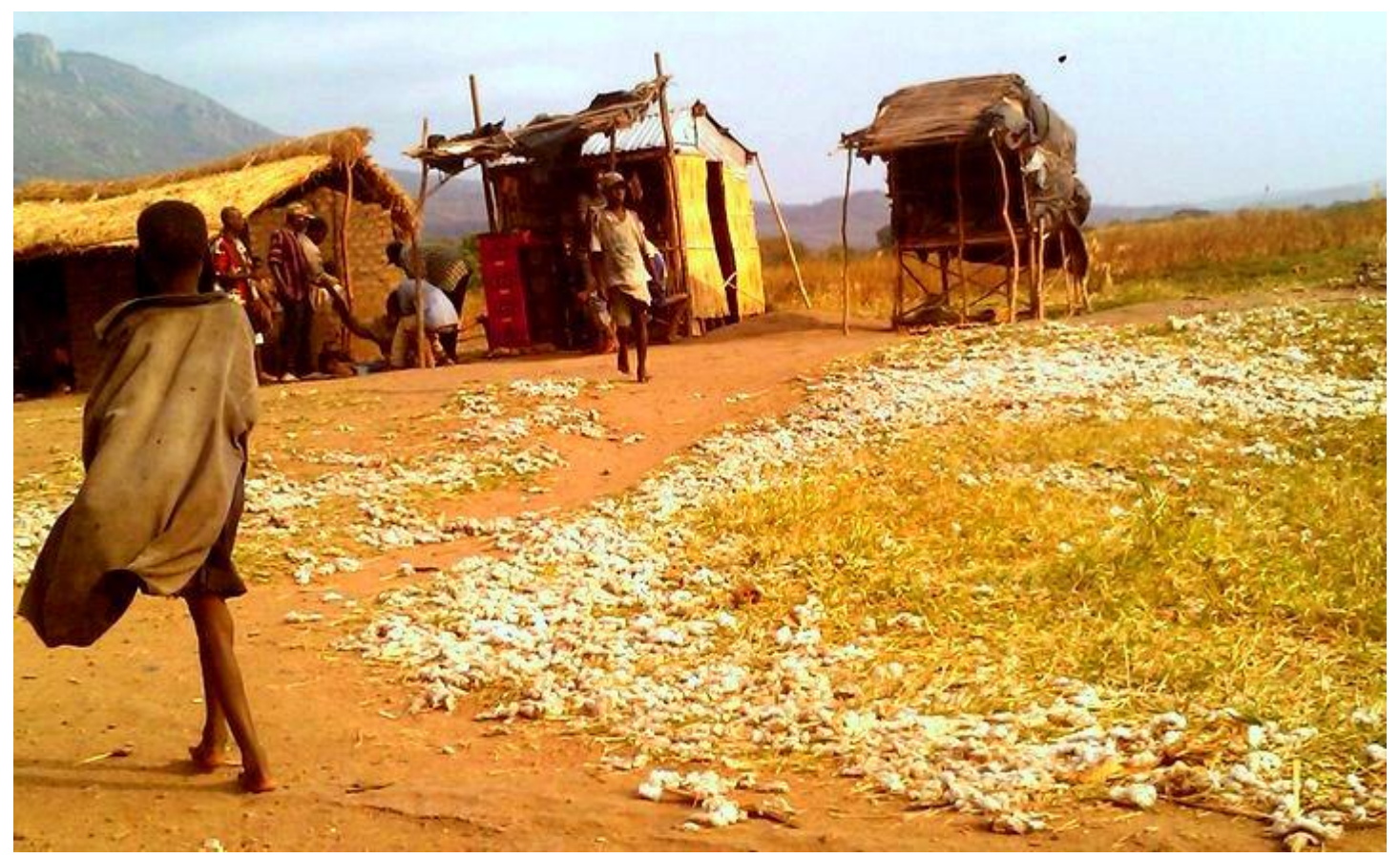

22

Foi muito transformador em vários sentidos. Incontáveis noites passei a conversar com os guardas da casa onde vivia, ambos com mais de 50 anos e membros muito respeitados da vila. Tinham uma vasta biblioteca que abriam e me contavam sempre que podiam durante as noites após o expediente enquanto tomávamos café. Eles realmente sentiam orgulho de contar suas estórias para mim, um branco.

21 Ver o site da universidade: http://www.flcs.uem.mz.

22 Menino caminhando ao lado de restos de algodão deixados no chão após embarque dos caminhões na balsa que cruza o rio Chire. Foto tirada por: Ruy Monteiro. 
Infelizmente, não há dúvida de que esse é um traço identitário que fez parte de todas as minhas experiências em todas as esferas em Moçambique. Seria ingenuidade negar, sobretudo lá quando esse dado se acirrou muito.

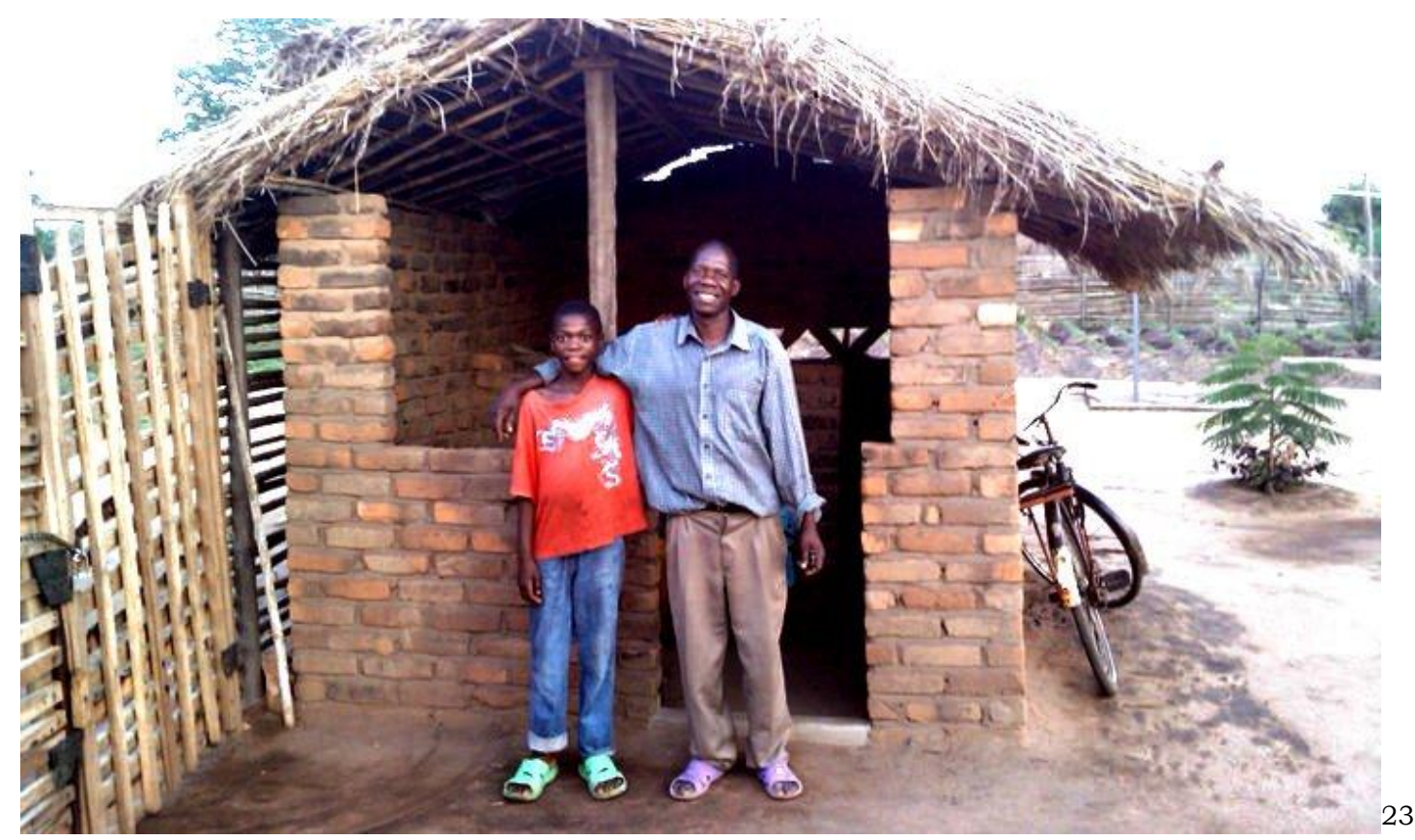

No transcurso desse ano inteiro assumi responsabilidades como supervisor de campo do projeto e me envolvi com o dia-a-dia dos outros membros da equipe, com as pessoas da vila, com os comerciantes pequenos, donos de lojas, membros do governo local, etc. Tudo se tornou ainda mais interessante quando executamos um diagnóstico nas comunidades com as quais iriamos trabalhar, isso porque era a primeira vez que saiamos do centro do distrito para ir de fato aos locais mais isolados conversar com as pessoas.

Toda a comunicação tinha que ser mediada por intérpretes das linguas locais, de forma que sempre que chegávamos a um lugar alguém era destacado para a função, porque muitas destas pessoas realmente não falavam a língua oficial, que é o português, sobretudo as mulheres. Atualmente, cerca de $45 \%$ das pessoas são alfabetizadas em

$23 \mathrm{Um}$ dos dois guardas, seu Antonio, com um de seus 15 filhos à frente da guarita que eles próprios construíram. Foto tirada por: Ruy Monteiro. 
português; sobre esse dado pesa a imensa deficiência de escolas tanto em âmbito rural quanto urbano.

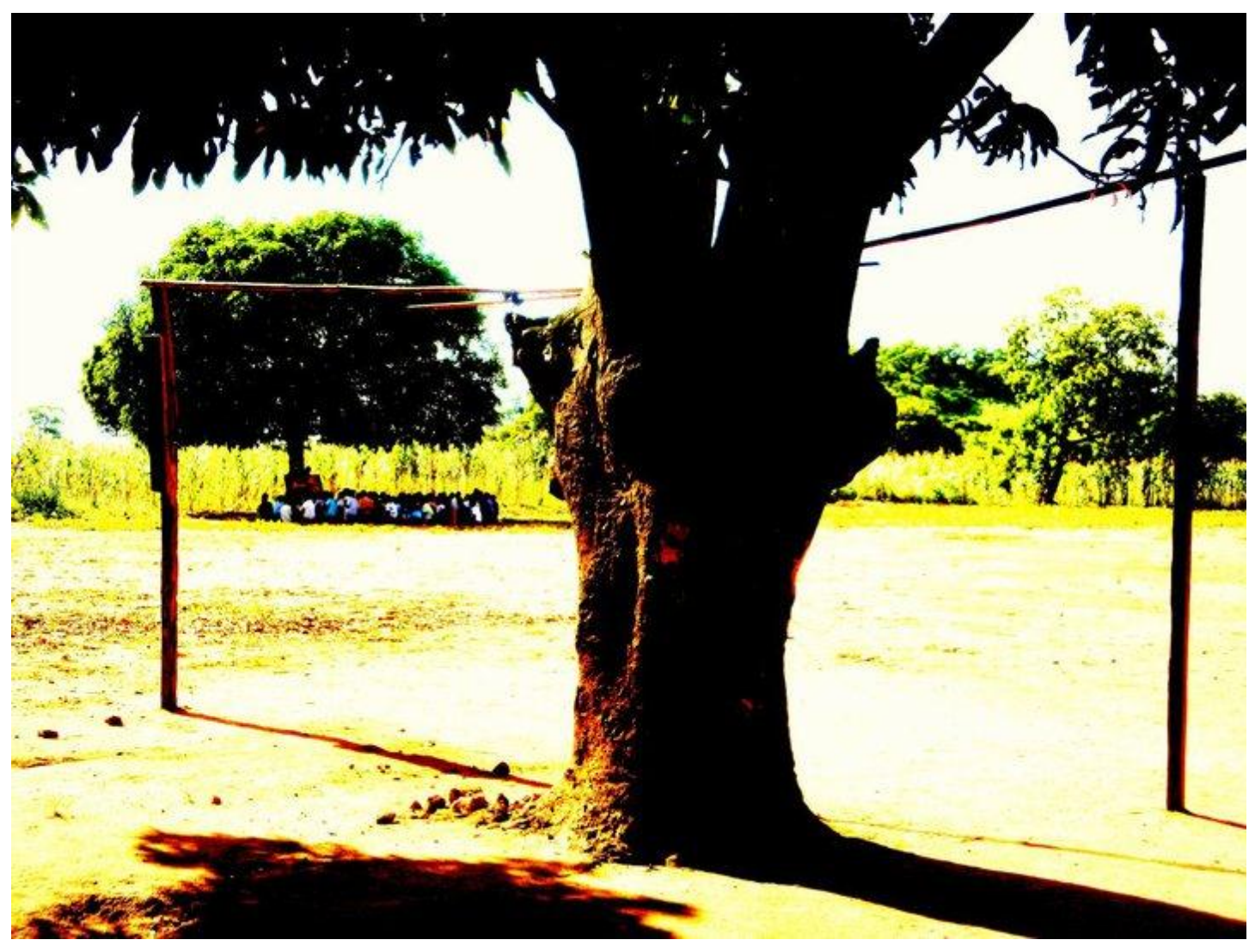

A infraestrutura local dos distritos que atendiamos, nomeadamente: Maringue, Morrumbala, Chemba, Mutarara e Maringue, forçava uma adaptação significativa com relação a certos dados do cotidiano. A inexistência de redes de saneamento, de água encanada, açougue, banco, vias asfaltadas e eletricidade forçavam um estilo de vida bastante restrito para os padrões aos quais estava acostumado.

24 Crianças em círculo em baixo de uma mangueira ouvindo a professora lecionar. Distrito de Morrumbala. 


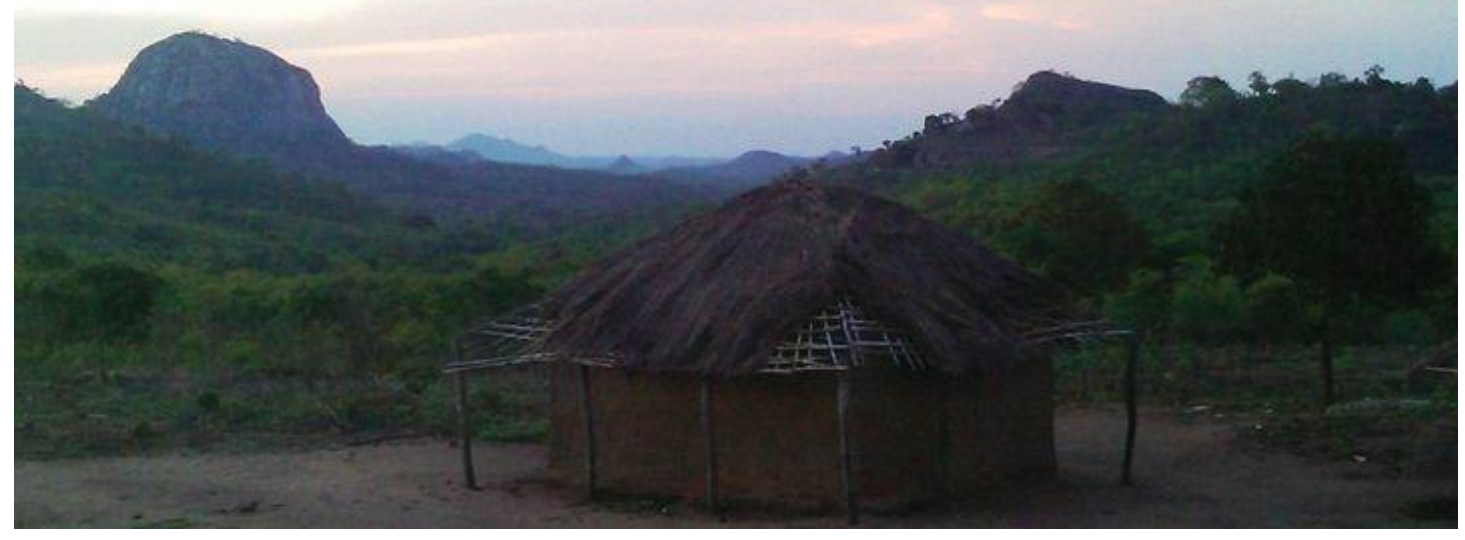

No interior ainda se vêem muitas marcas das guerras, por exemplo: casas, igrejas, galpões e às vezes todo o centro de vilas eram queimadas em ações terroristas dos grupos armados que circulavam por esses meios a procura de pequenos povoados mais frágeis. Carros blindados abandonados após enfrentamentos de tropas, marcas de tiro em paredes e trens queimados. Esses são indicadores de um tempo em que ocorreu um processo de convulsão do país em que os serviços básicos já não podiam ser garantidos, inclusive a segurança, o que fez com que grandes contingentes populacionais migrassem e assim causasse a desarticulação das cadeias produtivas e comerciais, acompanhado de todo um desarranjo institucional, falta de metas, planejamento e execução adequada quando existiam ações.

25 "Palhota" à beira de um vale repleto outras de famílias sem acesso a água, eletricidade, saneamento, escola etc. Cerca de 10 quilometros afastada da vila sede do distrito de Morrumbala. Foto tirada por: Ruy Monteiro. 


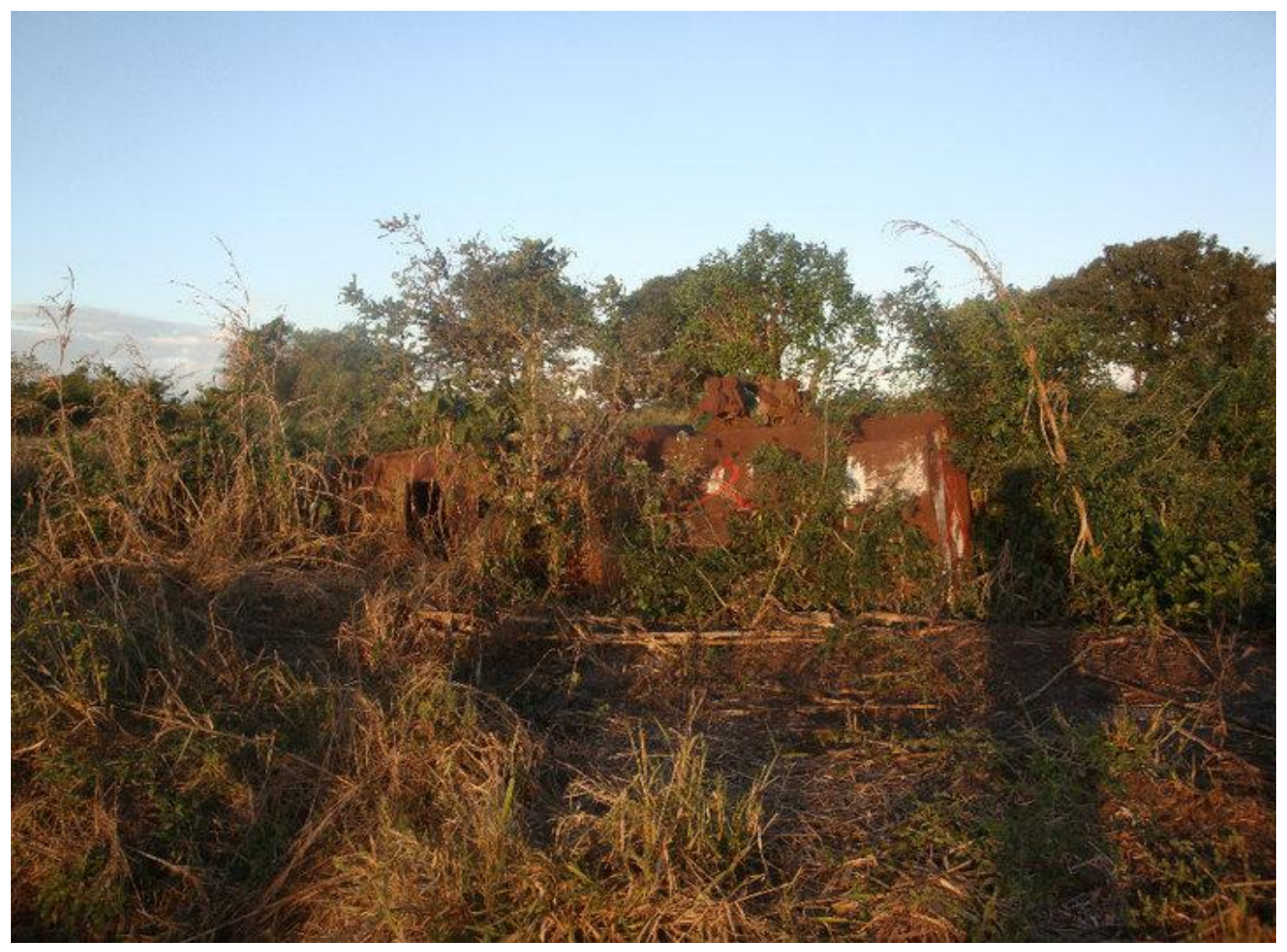

Este período durou de meados da década de sessenta até os primeiros anos da década de noventa, passando do colonialismo prélibertação até 1975 para um breve período alinhado ao bloco soviético com implantação de politicas socialistas entre 1975 e 1985, durante a guerra civil, a qual se seguiria pelas décadas de 80 e 90 numa catastrófica falência da economia até 1992, quando são assinados os acordos de paz. Nessa altura, o país já voltava a estar alinhado ao bloco capitalista, abraçando a economia de mercado e a ajuda externa aliada ao trabalho das grandes ONGs internacionais, apesar de manter a terra como propriedade do Estado e ceder seu uso sob o regime de concessão ou através do direito consuetudinário que as populações locais têm garantido segundo a transmissão oral desse direito pelos Régulos e/ou outros líderes locais como Mpfumos, Sapandas etc.

Parar terminar gostaria amarrar duas questões que foram apontadas logo no início do texto. A questão das reabilitações de infraestruturas, tratada quando nos referiamos ao aeroporto de Maputo

26 Carro blindado usado na guerra e deixado no mato após um ataque, possivelmente. Distrito de Maringue. Antiga sede da RENAMO durante a guerra civil. Trem saqueado também durante a guerra. Distrito de Mutarara, provincia de Tete. Fotos tiradas por: Ruy Monteiro. 
e a questão da simultaneidade entre fé e descrença no seio da sociedade moçambicana.

Vou citar outras três reabilitações que vêm sendo feitas no sentido de recolocar o país num processo de desenvolvimento a partir da criação de condições mínimas de segurança e lucratividade para os investimentos.

A primeira foi a finalização das obras da ponte Armando Emilio Guebuza sobre o Rio Zambeze em 2009, que estavam paradas acerca de 30 anos por conta dos conflitos e que respondeu a uma necessidade urgente que existia de se ligar as províncias do sul e centro com o norte do país no intuito de corrigir sérios entraves que existiam a melhor fluidez de pessoas e mercadorias no âmbito da economia nacional e regional. A segunda seria a reabilitação da ferrovia entre as cidades de Tete e Beira para transporte do carvão ao porto. Além dessas, inúmeras outras poderiam ser citadas.

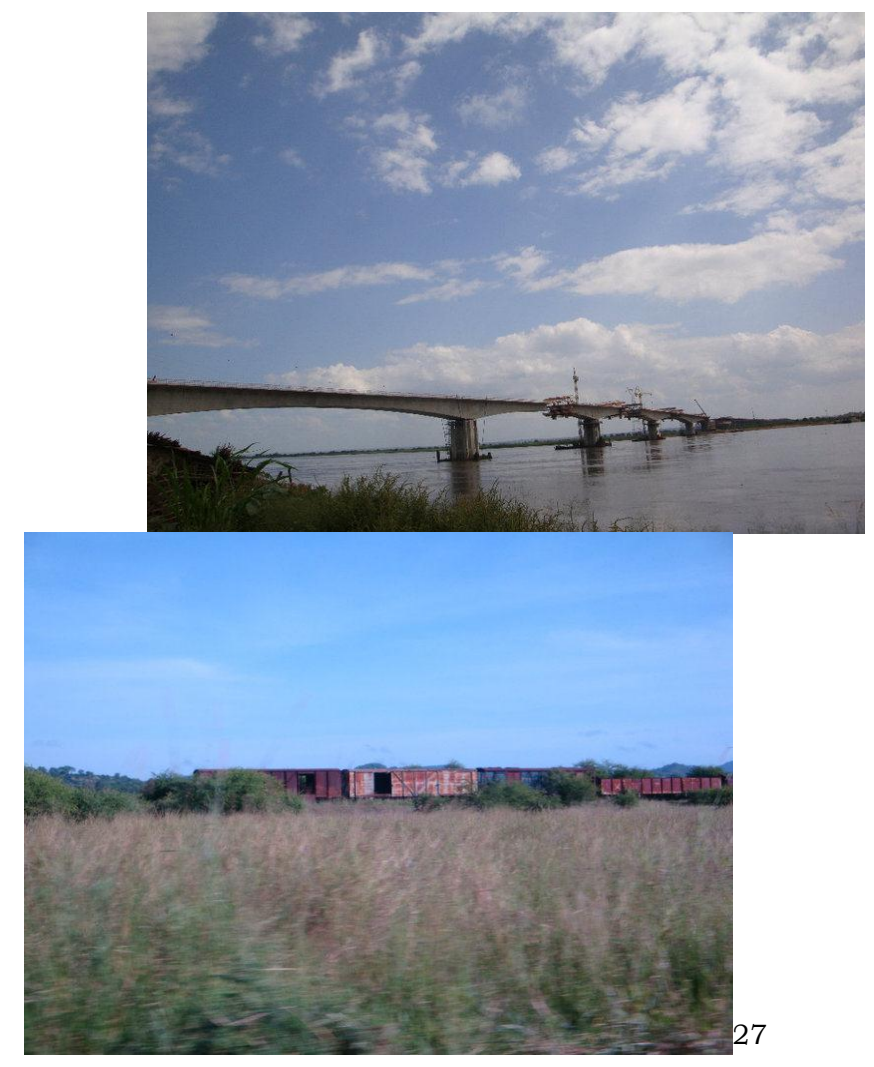

27 Da esquerda para a direita: 1 - Ponte Armando Emlio Guebuza sobre o rio Zambeze, inaugurada em 2009, num comício imenso do presidente, justamente no ano em que foi reeleito por mais 5 anos para o cargo. 2 - Trem saqueado também durante a guerra. Distrito de Mutarara, província de Tete. Fotos tiradas por: Ruy Monteiro. 
A terceira obra foi inaugurada recentemente, mas falo dela em separado, pois creio que se inscreva também numa categoria diferente de política pública, a qual se relaciona com a questão da identidade. Trata-se da construção do estádio nacional em Maputo, capital como forma de garantir um sentimento de pertença mútuo ao conjunto da sociedade e evitar regionalismos étnicos, etc.

$\mathrm{Na}$ esteira desse tema é que insiro a questão da descrença. O país parte de uma sociedade colonizada dualista para o sonho de libertação através do comunismo e da independência. Logo vê tudo isso se esboroar diante da realidade da queda do muro de Berlim, em associação com o empobrecimento inerente ao processo de guerra por que está passando. Então entra na economia de mercado numa posição muito desfavorável economicamente, totalmente dependente da ajuda externa (50\% do orçamento do Estado depende da ajuda), ao que podemos chamar de neocolonialismo.

Unindo as duas questões, parece-me que se está lutando para desenvolver, mas sem de fato quebrar as amarras que lhe prendem a uma posição dependente, ao que só poderá mesmo despontar a desesperança. 


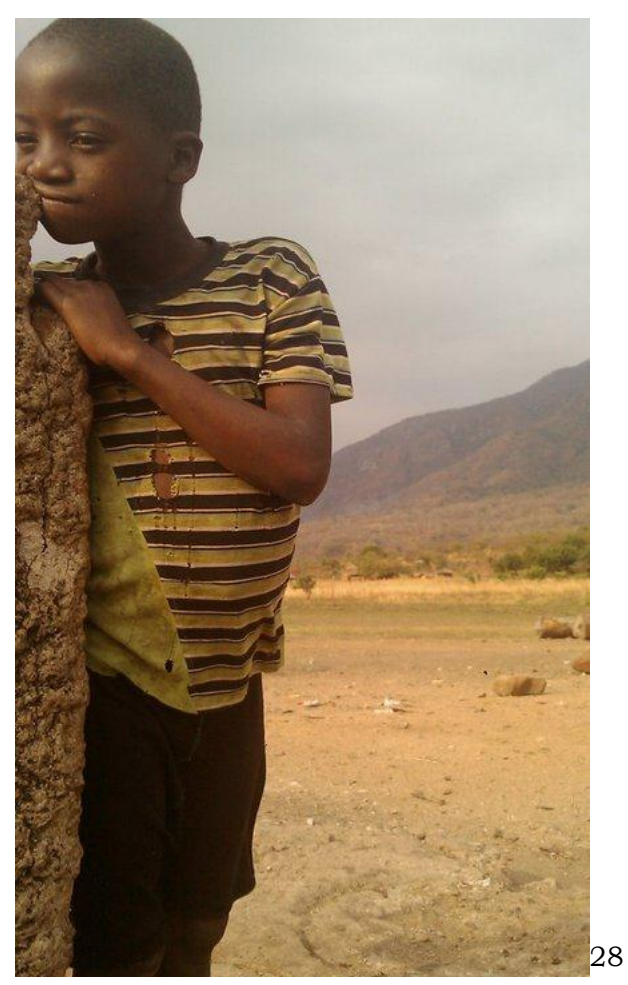

Apesar da análise feita acima, é necessário frisar que mesmo com toda a dificuldade na manutenção de algumas condições mínimas de estrutura urbana e rural existe um processo de reversão do quadro de miséria. Houve um tempo perdido na história, que ficou conhecido como o período da nudez, em que não havia sequer roupas para vestir. Hoje esse quadro é bastante diferente. É claro que há uma série de entraves, como a baixa capacidade produtiva, a ausência quase total de um empresariado formal, de mercado consumidor em escala, de parque industrial nacional, corrupção e a desigualdade, mas tem que se levar em conta o muito que já se tem feito. A foto abaixo resume um pouco desse momento.

28 Menino apoiado pensativo. Distrito de Morrumbala. Foto tirada por: Ruy 


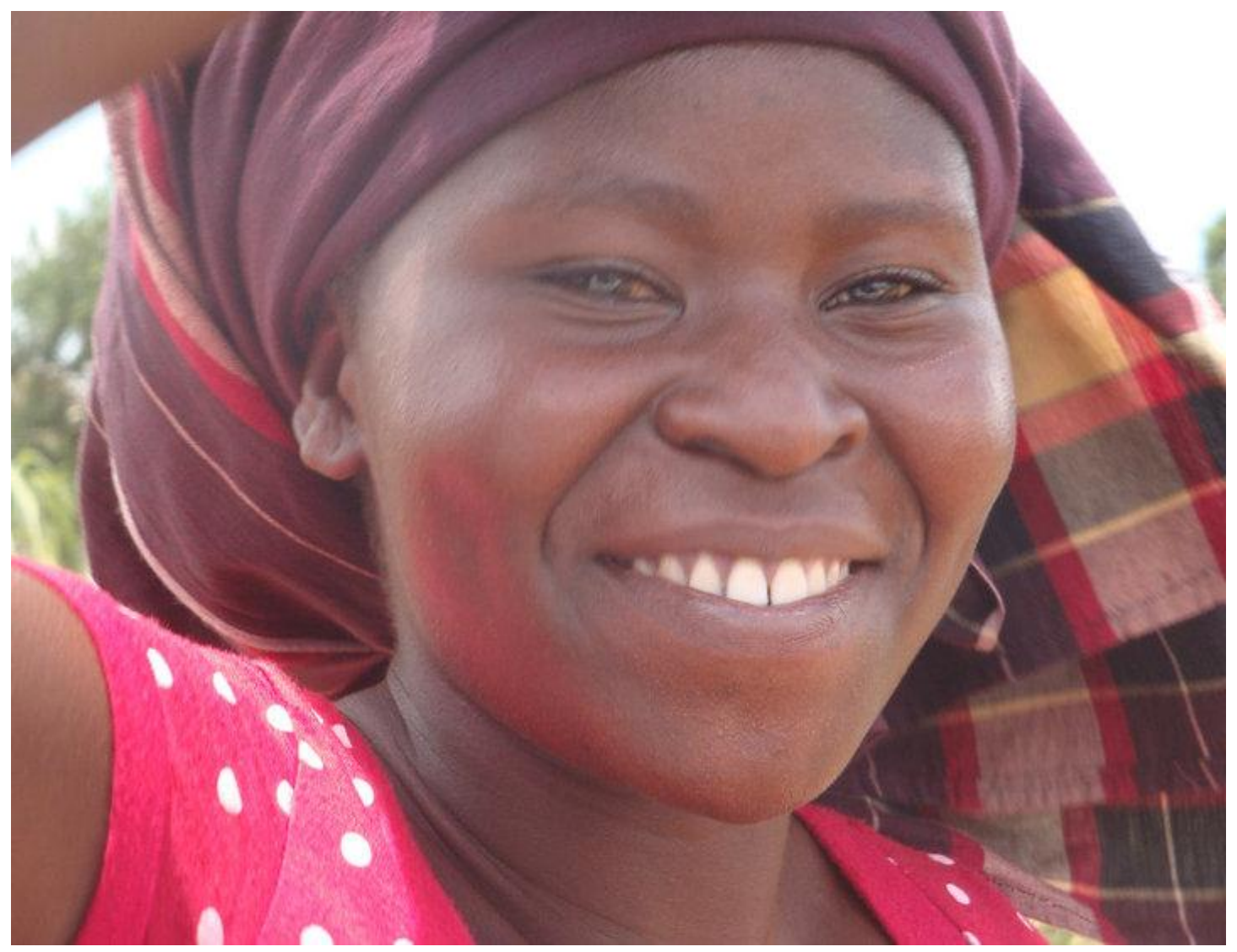

29 Moradora da zona rural do distrito de Morrumbala. Provincia da Zambézia. Foto tirada por: Ruy Monteiro. 